\title{
Pengurangan Pencemaran Udara berdasarkan Konsep Pelabuhan Hijau
}

\author{
CONNY KURNIAWAN WACHJOE ${ }^{1}$, HERMAGASANTOS ZEIN ${ }^{1}$, YANTI \\ SUPRIYANTI ${ }^{1}$, TINA MULYA GANTINA ${ }^{1}$, ANNISA KURNIASETIAWATI ${ }^{1}$, \\ PUREZA MARENSHAPUTRI ${ }^{2}$
}

${ }^{1}$ Teknik Konversi Energi Politeknik Negeri Bandung

2 PT Kereta Cepat Indonesia Cina

Email : ck_wachjoe@polban.ac.id

Received 12 November 2019 | Revised 15 Januari 2020 | Accepted 30 Februari 2020

\begin{abstract}
ABSTRAK
Perdagangan bebas antara negara-negara di dunia telah mengubah pergerakan orang dan barang yang memberi dampak signifikan pada pemanfaatan transportasi laut. Fenomena ini akan berdampak pada peningkatan jumlah kapal yang berlabuh di pelabuhan. Ketika catu daya listrik tidak tersedia untuk kapal di pelabuhan, mesin diesel kapal dioperasikan untuk memenuhi kebutuhan beban listrik selama proses bongkar muat. Pengoperasian mesin diesel akan berdampak negatif pada area pelabuhan karena kebisingan dan polusi udara. Makalah ini akan menyediakan metode pasokan daya shore to ship (STS) yang memasok listrik dari darat ke kapal. STS dapat digunakan untuk meningkatkan kualitas udara di area pelabuhan. Hasilnya telah secara signifikan mengurangi jumlah polusi udara berbahaya, terutama untuk emisi NOx, VOC, dan PM masing-masing sebesar 97\%, $94 \%$ dan $89 \%$.
\end{abstract}

Kata kunci: pelabuhan laut, pembangkit listrik tenaga diesel, shore to ship, berlabuh, emisi gas buang berbahaya

\begin{abstract}
Free trade agreements between countries in the world have changed the movement of people and goods which creates a significant impact on sea transportation. This phenomenon will have an impact on the rapid increase in the number of vessels resting at the port. When the electrical power supply is not available for ships in the port, the ship diesel engine is operated to meet the electrical load during the loading and unloading process. Operation of the diesel engine will have a negative impact on the port area due to noise and air pollution. This paper will provide a shore-to-ship (STS) power supply method that supplies electricity from land to ships. STS can be used to improve air quality in the port area. The results have significantly reduced the amount of harmful air pollution, especially for NOx, VOC, and PM emissions by 97\%, 94\% and 89\% respectively.
\end{abstract}

Keywords: port, diesel plant, shore to ship, berthing, harmful air polution 
Pengurangan Pencemaran Udara berdasarkan Konsep Pelabuhan Hijau

\section{PENDAHULUAN}

Transportasi laut memainkan peran penting dalam pergerakan transportasi barang dan orang di seluruh dunia. Demikian pula pergerakan barang antar pulau, khususnya di Indonesia sangat bergantung pada transportasi laut. Demikian pula, peningkatan daya tarik wisata pada suatu wilayah berdampak kepada pesatnya pertumbuhan jumlah kapal pesiar. Dengan demikian peningkatan kebutuhan transportasi laut menyebabkan tumbuh berkembangnya prasarana dermaga sebagai penunjang utama dalam pergerakan barang dan manusia (Borkowski \& Tarnapowicz, 2015) (Commission, 2010) (IMO, 2010) (Tarnapowicz, 2011). Keluar masuknya kapal laut pada suatu dermaga akan berpengaruh terhadap jumlah tambatan kapal di dermaga. Dipihak lain, peningkatan mobilisasi pergerakan kapal laut akan menyebabkan peningkatan jumlah kapal laut yang berlabuh di dermaga. Peranan dermaga menjadi sangat penting dalam mendukung efektifitas bongkar muat komoditas. Prasarana dermaga yang memadai akan mampu mengurangi lama berlabuh kapal. Kesiapan dermaga dalam meningkatkan layanan bongkar muat cepat dapat meningkatkan mobilisasi kapal laut tanpa perlu menambah jumlah dermaga pada suatu pelabuhan. Bongkar muat barang dan manusia dari kapal laut membutuhkan pasokan tenaga listrik sampai dengan kapal laut kembali berlayar (IMO, 2010). Pada umumnya catu tenaga listrik yang dibutuhkan setiap kapal dipenuhi oleh captive power berbasis pembangkit listrik tenaga diesel (PLTD) bila tidak dapat dipenuhi oleh tenaga listrik dari darat.

Pengoperasian PLTD oleh setiap kapal akan menghasilkan pengaruh negatif dari kapal pada lingkungan pantai dan pelabuhan, terutama polusi suara mesin dan polusi udara. Kapal adalah sumber polusi udara yang berkontribusi signifikan terhadap polusi udara, yang berasal dari emisi gas buang dalam bentuk: NOx, SOx, Particulate Matter, CO dan CO2 (Samosir, dkk, 2017) (MEPC, 2016) (Ocean-Going Ship Survey Summary of Results, 2007). Polusi udara terutama NOx dan SOx akan menyebabkan bahaya serius aglomerasi emisi udara di perkotaan sekitar pelabuhan. Secara umum setiap liter bahan bakar minyak solar yang dibakar akan menimbulkan emisi $\mathrm{CO}, \mathrm{CO}_{2}$, $\mathrm{NO}_{x}$ masing-masing sebesar $100 \mathrm{gram}, 2,5 \mathrm{~kg}$, dan 30 gram. Emisi gas buang dari mesin diesel mengakibatkan masalah terhadap lingkungan, hujan asam, efek gas rumah kaca, bahkan bagi kesehatan manusia terutama pada sistem pernapasan (Kumar, dkk, 2019).

Berdasarkan Organisasi Maritim Internasional batas berbahaya bagi komponen gas buang NOx dari kapal laut yang dipelajari oleh (MEPC, 2016) (Ferox, 2012) harus menurun dari level $10 \mathrm{gr} / \mathrm{kWh}$ pada tahun 2000 menjadi $4 \mathrm{gr} / \mathrm{kWh}$ pada tahun 2016. Berdasarkan penelitian dan survei telah diketahui bahwa penyebab utama polusi di pelabuhan adalah dari diesel engine (auxiliary engine), seperti emisi $\mathrm{NO}_{x}$ sebesar 11 ton/hari di pelabuhan Los Angeles dan Long Beach (IMO, 2010) (Entec, 2005). Kapal konvensional menggunakan diesel auxiliary engine untuk membangkitkan listrik sebagai sumber penerangan dan kebutuhan daya listrik seharihari bagi awak kapal dan proses bongkar muat barang. Kebutuhan listrik untuk kapal ini harus dipasok dari darat bila diinginkan pelabuhan hijau (green port).

Pada saat kapal laut merapat di dermaga, PLTD dan pembangkit uap (boiler) merupakan sumber utama emisi gas buang. PLTD dengan kapasitas normal menghasilkan tingkat kebisingan hingga $100 \mathrm{~dB}$ sedangkan pada PLTD dengan kapasitas lebih dari 1 MVA tingkat kebisingannya dapat mencapai $140 \mathrm{~dB}$ (Ashrae, 2002). Dengan substitusi captive power kapal dengan jaringan listrik di dermaga ke kapal dapat mengurangi emisi gas buang dan tingkat kebisingan di pelabuhan. Pasokan listrik ke kapal laut memberikan dampak positif lain terhadap keuntungan biaya komparatif konsumsi bahan bakar dengan harga listrik dari dermaga (Hayt, dkk, 2012). 
Pendekatan yang digunakan dalam tulisan ini yaitu dengan memasok tenaga listrik dari darat ke kapal laut yang disebut dengan shore to ship (STS) power supply (Berggren \& Zetterlund, 2003) (Brockmann, 2007). Dengan konsep ini kebutuhan daya listrik untuk operasi kapal disuplai dari jaringan listrik di darat dan mesin kapal wajib dimatikan. STS merupakan suatu sistem penyediaan listrik dari darat ke kapal pada saat berlabuh, yang menggantikan mesin diesel auxiliary kapal. Dengan demikian STS berfungsi untuk meningkatkan kualitas udara di pelabuhan dan kota dimana pelabuhan itu berada. Selain itu, STS juga dapat meminimasi emisi gas $\mathrm{CO}_{2}$, jika sumber listrik sistem tersebut berasal dari green power plant, seperti PLTA dan PLTPB yang tersambung dengan Gardu Induk di dermaga. Sistem tenaga listrik STS secara umum dapat ditunjukkan oleh Gambar 1.

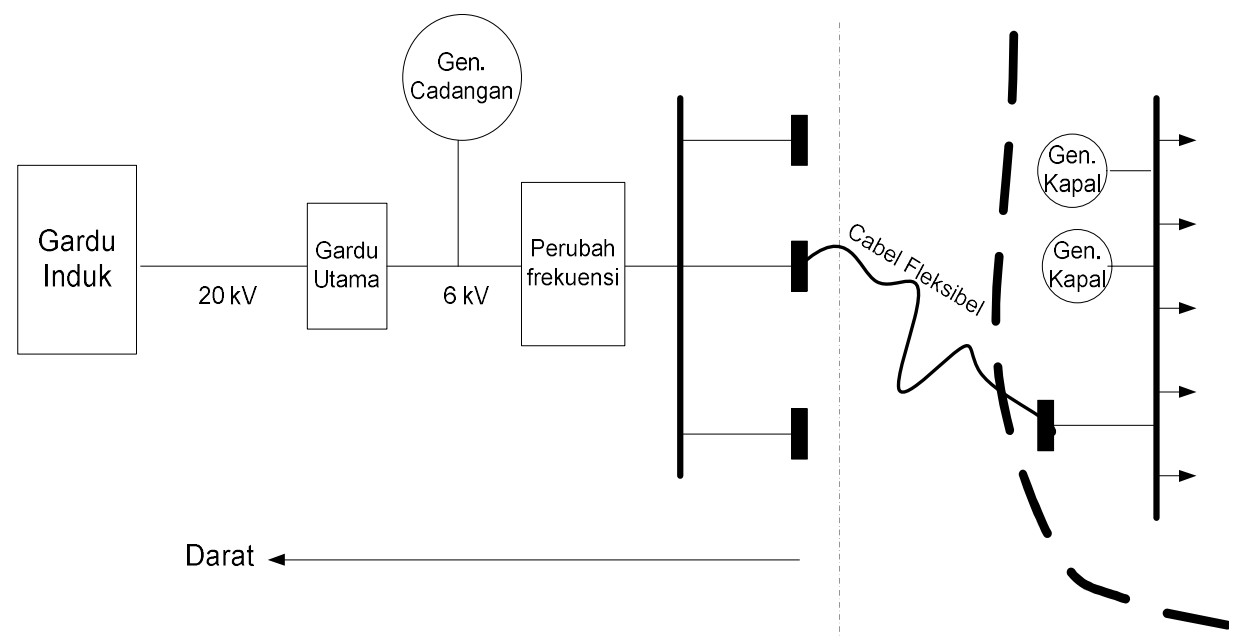

Gambar 1. Diagram Blok Sistem Shore to Ship

Gardu induk di darat yang menyuplai kapal sebagai sumber listrik utama. Di samping itu dermaga juga dilengkapi dengan generator cadangan yang berfungsi untuk meningkatkan keandalan pasokan. Feeder TM 20 kV masuk ke gardu utama yang berfungsi menurunkan tegangan menjadi $6 \mathrm{kV}$ (Hayt, dkk, 2012). Kemudian ada perubah frekuensi untuk menyesuaikan dengan sistem kelistrikan di kapal. Pada umumnya frekuensi ( $50 \mathrm{~Hz}$ atau 60 $\mathrm{Hz}$ ) dari setiap kapal sangat bergantung pada standardisasi dari negara kapal tersebut berasal. Sistem ini melayani tiga dermaga melalui bus-bar yang terhubung dengan tiga saluran. Pada ujung saluran itu ada soket daya yang berfungsi untuk menyambungkan kabel fleksibel. Kabel ini masuk ke dalam kapal melalui soket daya di kapal. Kemudian dilakukan sinkronisasi ke sistem listrik kapal (Brockmann, 2007) (MariTermAB, 2004). Setelah sinkron, generator pada kapal dimatikan.

Makalah ini menyajikan suatu usulan metode penentuan emisi gas buang dari mesin diesel dengan substitusi tenaga listrik dari darat ke kapal (STS). Metode ini menentukan dampak emisi gas buang yang dihasilkan oleh setiap kapal yang berlabuh. Besaran emisi gas buang yang dihasilkan mesin diesel didasarkan kepada total beban listrik setiap kapal pada waktu tertentu, jumlah konsumsi bahan bakar minyak, jumlah kapal yang berlabuh, sehingga emisi masing-masing jenis polutan yang dihasilkan. Energi listrik yang perlu disediakan ditentukan berdasarkan kebutuhan total dari jumlah kapal berlabuh di dermaga. Sedangkan jumlah kapal yang berlabuh di bandara disesuaikan dengan jumlah dan kapasitas dermaga yang tersedia di pelabuhan. Total kapal yang bisa berlabuh di satu dermaga ditentukan berdasarkan panjang rata-rata dermaga terhadap panjang kapal. 


\section{METODE}

Penentuan dampak emisi gas buang dari mesin diesel didasarkan kepada jumlah kapal dan lamanya berlabuh di dermaga. Disisi lain, kebutuhan tenaga listrik pada setiap kapal sangat dipengaruhi oleh kapasitas, jenis, penggunaan listrik kapal. Terkait dengan faktor-faktor penyebab emisi gas buang tersebut maka perhitungan besarnya substitusi daya listrik dari mesin diesel dengan tenaga listrik. Metode perhitungan tersebut dimulai dengan penentuan kebutuhan tenaga listrik sebagai fungsi dari beban total, jumlah, dan lama tertambat masingmasing kapal. Selanjutnya menentukan perkiraan konsumsi bahan bakar kapal sebagai fungsi dari total kebutuhan listrik dan efisiensi dari kapasitas masing-masing mesin diesel. Sehingga jumlah emisi gas buang yang dibangkitkan dapat ditentukan dari besarnya konsumsi bahan bakar minyak dengan faktor emisi untuk bahan bakar yang dikonsumsi mesin diesel.

\subsection{Prakiraan Kebutuhan Energi Listrik}

Pasokan energi listrik dari darat ke kapal laut didasarkan pada estimasi kebutuhan energi listrik di pelabuhan akan ditentukan oleh 3 faktor berikut ;

a) Tonase beban mati (DWT) masing-masing kapal

b) Jumlah kapal

c) Lama waktu berlabuh

Jumlah suatu jenis kapal berlabuh dalam satu jam dapat dihitung dari jumlah kapal tersebut berlabuh dalam suatu periode dan lamanya berlabuh, diekspresikan oleh Persamaan (1).

$$
N=\frac{M}{T}(t+\Delta t)
$$

Dimana:

$N \quad$ adalah jumlah kapal berlabuh dalam periode waktu $\mathrm{T}$

$M \quad$ adalah jumlah dermaga di pelabuhan

$T \quad$ adalah periode waktu dalam satuan jam

$t \quad$ adalah lama waktu berlabuh kapal di dermaga dalam satuan jam

$\Delta t \quad$ adalah perkiraan waktu rata-rata tunda dalam satuan jam

Dari Persamaan (1) dapat diturunkan jumlah energi yang dibutuhkan pada suatu pelabuhan laut bila menggunakan STS sebagai pencatu daya. Besarnya daya listrik terpasang pada suatu dermaga diasumsikan sama dengan kapasitas maksimum kapal laut yang tertambat pada setiap dermaga.

$$
E=\sum_{i=1}^{m} N_{i} P_{i} \mathrm{f}
$$

\section{Dimana:}

E adalah jumlah energi listrik (MWh)

$m \quad$ adalah jumlah jenis kapal

$P \quad$ adalah beban kapal (MW)

$T$ adalah lama berlabuh (jam)

f adalah waktu (jam)

\subsection{Estimasi Kebutuhan BBM}

Perkiraan kebutuhan BBM dapat diturunkan dari kebutuhan energi listrik. Konversi satu liter BBM ke Btu adalah diselesaikan dengan Persamaan (3). Perbedaan kapasitas mesin diesel yang digunakan oleh kapal laut akan menyebabkan perbedaan efisiensinya. 


$$
B=k E / \text { eff }
$$

Dimana:

$B \quad$ adalah jumlah BBM (liter)

$k=92,92 \quad$ adalah konstanta dari konversi BBM ke Btu dan MWh ke Btu

E adalah energi listrik (MWh)

eff adalah efisiensi berdasarkan kapasitas kapal

\subsection{Estimasi Emisi Gas Buang}

Jadi dalam suatu periode produksi emisi oleh PLTD kapal dapat ditentukan melalui Persamaan (4).

$$
E M_{i}=B \rho_{i}
$$

Dimana:

$E M_{i} \quad$ adalah jumlah emisi untuk jenis emisi i (misal emisi NOx) dalam satuan $\mathrm{kg} / \mathrm{t}$.

$\rho_{i} \quad$ adalah jumlah emisi i yang dihasilkan oleh PLTD kapal bila menggunakan 1 liter BBM.

\section{HASIL DAN DISKUSI}

Peluang penerapan sistem STS untuk mengurangi dampak polusi udara dan kebisingan kapal laut dengan menyiapkan pasokan tenaga listrik darat. Pasokan energi listrik dari darat (gardu induk) merupakan suatu pilihan pasokan tenaga listrik kapal sebagai sumber listrik utama. Studi kasus di Pelabuhan Tanjung Priuk merupakan acuan dalam kajian peluang penurunan emisi gas buang. Sebagai perbandingan total emisi gas buang yang dihasilkan oleh sistem terintegrasi dengan PLTD diperlihatkan pada Tabel 1 (Patrik, 2008). Pelabuhan Tanjung Priuk merupakan Pelabuhan Utama dari PT Pelabuhan Indonesia II (Persero) dan pelabuhan terbesar di Indonesia. Pada tahun 2011 arus kunjungan kapal ke Pelabuhan Tanjung Priuk mencapai 14.425 unit ship call antar pulau dan 4.489 unit ship call untuk kapal ocean going vessel. Kerena jumlah kunjungan kapal yang sangat padat maka emisi di Pelabuhan Tanjung Priuk juga meningkat tajam. Ini adalah salah satu sumber polusi udara di Jakarta.

Tabel 1. Komposisi Emisi dari Gas Buang untuk 1 Liter BBM PLTD (Patrik, 2008)

\begin{tabular}{|l|c|c|c|c|}
\hline \multicolumn{1}{|c|}{ Jenis } & $\begin{array}{c}\mathbf{N O x} \\
{[\mathbf{g} / \mathbf{k W h}]}\end{array}$ & $\begin{array}{c}\mathbf{S O}_{\mathbf{2}} \\
{[\mathbf{g} / \mathbf{k W h}]}\end{array}$ & $\begin{array}{c}\mathbf{V O C} \\
{[\mathbf{g} / \mathbf{k W h}]}\end{array}$ & $\begin{array}{c}\mathbf{P M} \\
{[\mathbf{g} / \mathbf{k W h}]}\end{array}$ \\
\hline $\begin{array}{l}\text { Faktor emisi rata-rata produksi } \\
\text { listrik di Eropa }\end{array}$ & 0,35 & 0,46 & 0,02 & 0,03 \\
\hline $\begin{array}{l}\text { Faktor emisi dari auxiliary engine } \\
\text { untuk BBM ber sulfur 0,1\% }\end{array}$ & 11,8 & 0,46 & 0,40 & 0,30 \\
\hline
\end{tabular}

Penerapan metode pendekatan pengurangan emisi gas buang dari kapal laut yang berlabuh ke dermaga, didasarkan kepada besarnya emisi gas buang spesifik (Ferox chart, 2012) untuk masing-masing jenis bahan bakar yang diperlihatkan pada Tabel 2 . Tabel 2 menunjukkan bahwa faktor emisi gas buang yang berbahaya terutama adalah $\mathrm{NOx}$ dan $\mathrm{SO}_{2}$ karena dapat menyebar di sekitar dermaga. Emisi gas buang $\mathrm{SO}_{2}$ dari pembangkit listrik tenaga diesel dapat mengakibatkan hujan asam. Walaupun emisi VOC dan PM relatif rendah dibandingkan dengan dua emisi pertama namun dapat berbahaya bagi kesehatan bila terhirup manusia. 
Tabel 2. Emisi Gas Buang berdasarkan Bahan Bakar (Ferox, 2012)

\begin{tabular}{|l|c|c|c|c|}
\hline \multicolumn{1}{|c|}{ Tipe bahan bakar } & $\begin{array}{c}\text { SOx } \\
\text { (g/kWh) }\end{array}$ & $\begin{array}{c}\text { NOx } \\
\text { (g/kWh) }\end{array}$ & $\begin{array}{c}\text { PM } \\
\text { (g/kWh) }\end{array}$ & $\begin{array}{c}\mathbf{C O}_{2} \\
\text { (g/kWh) }\end{array}$ \\
\hline Residual oil 3.5\% Sulphur & 13 & $9-12$ & 1.5 & $580-630$ \\
\hline Marine diesel oil, 0.5\% Sulphur & 2 & $8-11$ & $0.25-0.5$ & $580-630$ \\
\hline Gasoil 0.1\% Sulphur & 0.4 & $8-11$ & $0.15-0.25$ & $580-630$ \\
\hline Natural gas (LNG) & 0 & 2 & 0 & $430-480$ \\
\hline
\end{tabular}

Dari Tabel 2, besaran emisi gas buang akan sangat signifikan bila mesin diesel menggunakan bahan bakar minyak solar dengan kadar sulfur yang tinggi. Perkiraan pengurangan polusi udara dapat dihitung dari jumlah BBM yang digunakan dalam suatu periode waktu oleh PLTD kapal-kapal akan mengeluarkan emisi pada gas buangnya. Matrik jenis dan jumlah kapal yang beroperasi (Patrik, 2008) akan berkontribusi pada emisi gas buang berbahaya ditunjukkan pada Tabel 3.

Tabel 3. Data Jumlah Kapal Berlabuh (Patrik, 2008)

\begin{tabular}{|c|c|c|c|c|c|c|c|c|c|}
\hline \multirow[b]{2}{*}{ Bulan } & \multicolumn{9}{|c|}{ Jenis Kapal } \\
\hline & CARGO & $\begin{array}{c}\text { CURAH } \\
\text { CAIR } \\
\text { NON } \\
\text { BBM }\end{array}$ & $\begin{array}{c}\text { CURAH } \\
\text { KERING }\end{array}$ & $\begin{array}{c}\text { KHUSUS } \\
\text { IN- } \\
\text { DUSTRI }\end{array}$ & RORO & $\begin{array}{c}\text { SEMI } \\
\text { CONTAI- } \\
\text { NER }\end{array}$ & TANKER & $\begin{array}{l}\text { TONG- } \\
\text { KANG }\end{array}$ & $\begin{array}{c}\text { CON- } \\
\text { TAINER }\end{array}$ \\
\hline \begin{tabular}{|l} 
Januari \\
\end{tabular} & 221 & 12 & 18 & 27 & 134 & 77 & 121 & 270 & 428 \\
\hline Februari & 197 & 12 & 11 & 14 & 145 & 75 & 121 & 272 & 408 \\
\hline Maret & 219 & 12 & 12 & 8 & 163 & 77 & 127 & 257 & 438 \\
\hline April & 240 & 13 & 13 & 3 & 149 & 62 & 115 & 241 & 437 \\
\hline Mei & 222 & 11 & 16 & 6 & 164 & 72 & 117 & 270 & 420 \\
\hline Juni & 227 & 12 & 12 & 5 & 158 & 72 & 113 & 249 & 442 \\
\hline Juli & 228 & 13 & 13 & 12 & 182 & 65 & 108 & 287 & 437 \\
\hline \begin{tabular}{|l|} 
Agustus \\
\end{tabular} & 166 & 11 & 10 & 6 & 150 & 38 & 96 & 204 & 382 \\
\hline September & 193 & 15 & 14 & 6 & 170 & 62 & 102 & 273 & 452 \\
\hline Oktober & 218 & 16 & 9 & 8 & 174 & 55 & 105 & 281 & 461 \\
\hline November & 218 & 15 & 15 & 8 & 190 & 51 & 100 & 280 & 432 \\
\hline \begin{tabular}{|l|} 
Desember \\
\end{tabular} & 128 & 6 & 10 & 7 & 102 & 29 & 58 & 163 & 266 \\
\hline Total & 2477 & 148 & 153 & 110 & 1881 & 735 & 1283 & 3047 & 5003 \\
\hline
\end{tabular}

Dari Tabel 3 terlihat bahwa kontribusi kapal yang beroperasi di Tanjung Priuk didominasi oleh kapal kontainer. Hal ini menunjukkan bahwa mobilisasi barang sangat tinggi dan dengan kapasitas kapal yang besar. Penentuan jumlah emisi yang dihasilkan oleh setiap kapal didasarkan lama sandar kapal di dermaga sehingga sangat berpengaruh terhadap jumlah total emisi gas buang. Lama sandar dan konsumsi energi listrik dari setiap kapal dapat dilihat pada Tabel 4.

Berdasarkan informasi yang tertuang pada Tabel 3 dan Tabel 4, maka besarnya kebutuhan tenaga listrik dapat dihitung melalui Persamaan (2) dan Persamaan (3), dan perkiraan konsumsi bahan bakar minyak pada periode tertentu dapat ditentukan melalui Persamaan (3). Sedangkan jumlah dampak emisi gas buang pada periode tersebut dapat ditentukan berdasarkan Tabel 2 dan Persamaan (4). 
Wachjoe, dkk

Tabel 4. Distribusi Konsumsi Daya Listrik Kapal dan Lama Waktu Berlabuh

\begin{tabular}{|l|c|c|}
\hline \multicolumn{1}{|c|}{ Jenis kapal } & Daya (MWe) & Durasi berlabuh rata-rata (jam) \\
\hline CARGO & 0.7 & 38.2 \\
\hline CURAH CAIR NON BBM & 3 & 36.4 \\
\hline CURAH KERING & 0.7 & 39.6 \\
\hline KHUSUS INDUSTRI & 2 & 41.9 \\
\hline RORO & 0.7 & 20.9 \\
\hline SEMI CONTAINER & 2 & 28.5 \\
\hline TANKER & 3 & 37.9 \\
\hline TONGKANG & 0.7 & 40.1 \\
\hline CONTAINER & 2 & 26.7 \\
\hline
\end{tabular}

Polusi udara dapat dihitung dari jumlah BBM yang digunakan dalam suatu periode oleh PLTD kapal-kapal mengeluarkan emisi pada gas buangnya. Hasil simulasi diperlihatkan pada Tabel 5. Pengaruh lama berlabuh dari setiap kapal sangat signifikan terhadap emisi gas buang yang dihasilkan oleh mesin diesel. Selain menghasilkan emisi gas buang yang berbahaya, pengoperasian mesin diesel juga menyebabkan biaya operasi yang tinggi akibat konsumsi minyak solar.

Tabel 5. Pengurangan Emisi dengan menggunakan STS

\begin{tabular}{|c|c|c|c|c|}
\hline $\begin{array}{l}\text { Jenis } \\
\text { Emisi }\end{array}$ & Kategori Emisi & $\begin{array}{c}\text { Kecil } \\
\text { (Ton/year) }\end{array}$ & $\begin{array}{c}\text { Sedang } \\
\text { (Ton/year) }\end{array}$ & $\begin{array}{c}\text { Besar } \\
\text { (Ton/year) }\end{array}$ \\
\hline NOx & $\begin{array}{l}\text { Emisi baseline } \\
\text { Pengurangan emisi } \\
\text { Efisiensi pengurangan }\end{array}$ & $\begin{array}{l}15,3 \\
13,3 \\
81 \%\end{array}$ & $\begin{array}{l}42,4 \\
38,5 \\
91 \%\end{array}$ & $\begin{array}{l}109,1 \\
105,8 \\
97 \%\end{array}$ \\
\hline 9SOx & $\begin{array}{l}\text { Emisi baseline } \\
\text { Pengurangan emisi } \\
\text { Efisiensi pengurangan }\end{array}$ & $\begin{array}{l}0,62 \\
0,0 \\
0 \%\end{array}$ & $\begin{array}{l}1,72 \\
0,0 \\
0 \%\end{array}$ & $\begin{array}{l}4,44 \\
0,0 \\
0 \%\end{array}$ \\
\hline VOC & $\begin{array}{l}\text { Emisi baseline } \\
\text { Pengurangan emisi } \\
\text { Efisiensi pengurangan }\end{array}$ & $\begin{array}{l}0,52 \\
0,41 \\
79 \%\end{array}$ & $\begin{array}{l}1,44 \\
1,27 \\
88 \%\end{array}$ & $\begin{array}{l}3,71 \\
3,49 \\
94 \%\end{array}$ \\
\hline PM & $\begin{array}{l}\text { Emisi baseline } \\
\text { Pengurangan emisi } \\
\text { Efisiensi pengurangan }\end{array}$ & $\begin{array}{l}0,39 \\
0,29 \\
75 \%\end{array}$ & $\begin{array}{l}1,08 \\
0,90 \\
83 \%\end{array}$ & $\begin{array}{l}2,78 \\
2,47 \\
89 \%\end{array}$ \\
\hline
\end{tabular}

Dari Tabel 5 terlihat bahwa pengaruh komponen emisi gas buang berbahaya bagi lingkungan adalah emisi NOx. Reduksi emisi NOx dengan pendekatan ini berkontribusi sangat signifikan sebesar $97 \%$. Sedangkan emisi sulfur tidak tampak dikarenakan kualitas bahan bakar diesel tidak mengandung unsur sulfur. Berdasarkan hasil perhitungan, besarnya pengurangan emisi gas buang berbahaya akibat penerapan STS pada dermaga diperlihatkan pada Gambar 2. 
Pengurangan Pencemaran Udara berdasarkan Konsep Pelabuhan Hijau

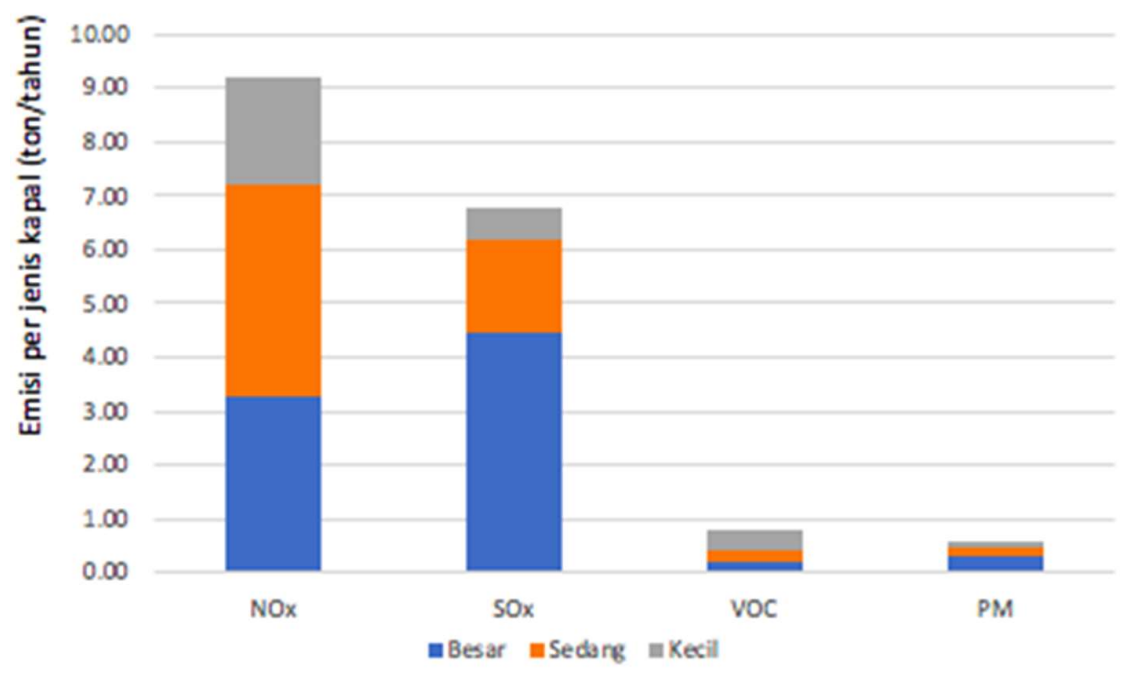

Gambar 2. Dampak Emisi Gas Buang per Kapasitas Kapal

Gambar 2 memperlihatkan total emisi gas buang berbahaya $\mathrm{NO}_{\mathrm{x}}$ dari kapal yang berlabuh di pelabuhan dari mesin diesel sebesar 166,8 ton/tahun menjadi 9,2 ton/tahun dengan menerapkan STS. Demikian pula penurunan dari emisi gas buang VOC dan PM menjadi masing-masing sebesar 0,51 ton/tahun dan 0,59 ton/tahun.

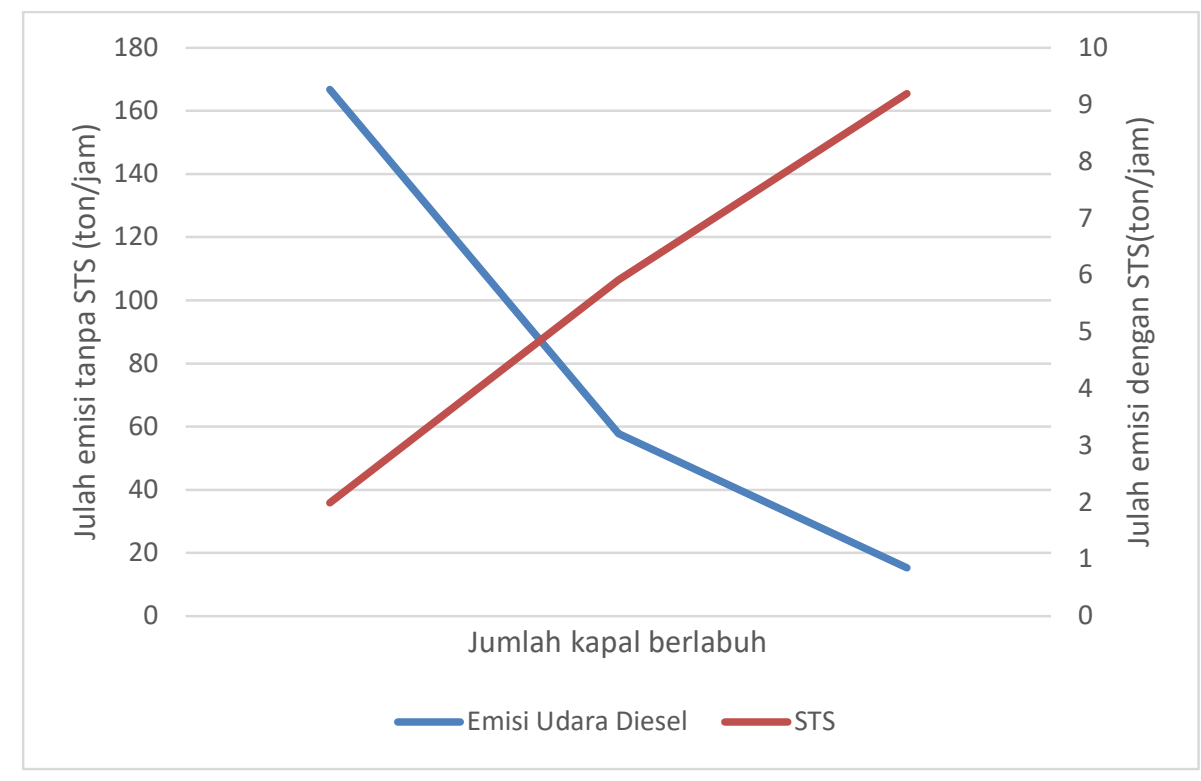

Gambar 3. Perbandingan Emisi Gas Buang NOx dari Diesel terhadap STS

Gambar 3 menunjukkan bahwa total emisi gas buang berbahaya $\mathrm{NO}_{x}$ yang dihasilkan mesin diesel sangat bergantung dari jumlah kapal yang berlabuh di pelabuhan. Bila terjadi seluruh dermaga penuh pada saat bersamaan maka terjadi maksimum total emisi $\mathrm{NO}_{x}$ dari mesin diesel sebesar 167 ton/jam. Dengan memanfaatkan STS untuk kompensasi seluruh kebutuhan listrik dermaga maka total emisi $\mathrm{NO}_{x}$ hanya sebesar 9 ton/jam pada periode yang sama.

Kondisi saat sistem tenaga listrik dari gardu induk hanya mampu memasok untuk dermaga kapal besar saja, maka total emisi $\mathrm{NO}_{x}$ yang dihasilkan berasal dari dermaga kapal sedang dan 
kapal kecil ditambah dari delay kompensasi STS. Total emisi $\mathrm{NO}_{\mathrm{x}}$ pada kondisi tersebut sebesar 64 ton/jam dalam kategori cukup berbahaya bagi manusia.

Berdasarkan jenis emisi yang dominan dan berbahaya bagi lingkungan dengan metode yang dibangun dan dengan informasi data beban dermaga serta jumlah dan jenis kapal maka total konsumsi energi PLTD yang akan disubstitusi listrik darat dari seluruh kapal yang berlabuh di pelabuhan dapat ditentukan. Kapasitas daya listrik terpasang merupakan beban maksimum dari total kapal laut yang merapat di pelabuhan. Gardu Induk yang memasok daya listrik ke dermaga sesuai dengan kebutuhan total beban dermaga dan fasilitas pendukung lainnya (termasuk ruang tunggu, bea cukai, pemadam kebakaran, dll).

Perkiraan dampak emisi gas buang akibat kegiatan bongkar muat kapal di dermaga telah dapat ditentukan berdasarkan metode yang dibangun. Metode ini telah secara signifikan menurunkan jumlah emisi gas buang berbahaya (Tabel 5), khususnya untuk emisi $\mathrm{NO}_{x}$ dari kapal kecil, sedang, dan besar masing-masing sebesar $81 \%, 91 \%$, dan $97 \%$. Sedangkan untuk emisi VOC dari kapal kecil, sedang, dan besar masing-masing berkurang sebesar 79\%, 88\%, dan 94\%. Demikian pula untuk emisi PM berkurang sebesar 75\%, 83\%, dan 89\% untuk setiap kapasitas kapal yang berlabuh. Dengan demikian dampak positif lainnya yaitu meningkatkan nilai tambah pelabuhan akibat konsumsi energi listrik dari kapal yang berlabuh. Konsep STS merupakan pendekatan yang secara optimal dapat mengurangi emisi gas buang sehingga dapat menjaga kelestarian lingkungan (green port technology). Pengintegrasian sistem jaringan nasional dengan kebutuhan energi listrik di dermaga untuk kapal-kapal berlabuh selain dapat meningkatkan load factor karena beban mendekati nilai rata-rata selama 24 jam dan dapat mengurangi dampak emisi gas buang berbahaya. Pengaruh peningkatan faktor daya dapat menurunkan secara langsung biaya pembangkitan sistem tenaga listrik nasional.

\section{KESIMPULAN}

Penerapan metode berbasis substitusi pasokan energi listrik darat ke kapal berlabuh telah berhasil mengurangi emisi gas buang yang signifikan sehingga dapat menjaga kelestarian lingkungan (green port technology). Reduksi emisi berbahaya $\mathrm{NO}_{x}$ dengan pendekatan ini berkontribusi sangat signifikan rata-rata sebesar $90 \%$ dari baseline. Emisi VOC berkurang sebesar $\mathbf{8 7 \%}$ dibandingkan dengan nilai emisi tanpa menggunakan listrik darat. Sedangkan emisi PM berkurang sebesar $82 \%$. Secara nominal, penurunan emisi $\mathrm{NO}_{\mathrm{x}}$, VOC dan PM dari masing-masing sebesar 166,8 ton/tahun, 5,67 ton/tahun, dan 4,25 ton/tahun menjadi hanya sebesar 9,2 ton/tahun, 0,51 ton/tahun, dan 0,59 ton/tahun. Demikian pula dengan pengintegrasian sistem jaringan nasional dengan kebutuhan energi listrik di dermaga untuk kapal-kapal berlabuh dapat meningkatkan load factor pada sistem tenaga listrik karena beban hampir rata selama 24 jam.

\section{DAFTAR RUJUKAN}

Ashrae. (2002). Technical Commitee Sound and Vibration Generator Noise Control, An Overview. Atlantic City New Jersey, USA: Ashrae TC 2.6.

Berggren, J., \& Zetterlund, N. (2003). Electrical Shore Connection of SCA Transforest RoRovessels at the Port of Sundsvall. Goteborg: Goteborg University School of Economics and Commercial Law. 
Borkowski, T., \& Tarnapowicz, D. (2015). "Shore To Ship" System - An Alternative Electric Power Supply In Port. Journal of KONES, 19(3), 49-58.

Brockmann, D. (2007). SAM Electronics - We are connectiong ships with alternative maritime power SAMCon Terminal Antwerpen.

Commission, H. (2010). Working Paper On Helcommaritime Actions And Corresponding Actions Under The Action Plan For The Eustrategy For The Baltic Sea Region. Norrkoping, Sweden: Maritime Group.

Entec. (2005). Service contract on ship emissions: Assignment, abatement and marked based instruments - task2a - Shore side Electricity. Norwich: Entec UK Limited.

Ferox. (2012). CHART. Ferox. LNG ship fueling.

Hayt, W. H., Kemmerly, J. E., \& Durbin, S. M. (2012). Engineering Circuit Analysis, 8th edition. New York: The McGraw-Hill Companies Inc.

IMO. (2010). Prevention of Air Pollution from Ships. International Maritime Organization.

Kumar, J., Kumpulainen, L., \& Kauhaniemi, K. (2019). Technical design aspects of harbour area grid for shore to ship power: State of the art and future solutions. International Journal of Electrical Power \& Energy Systems, 840-852.

MariTermAB. (2004). Shore-side Electricity for Ships in Ports, Case studies with estimates of internal and external costs. Gothenburg: North Sea Commission.

MEPC. (2016). Amendments To The 2010 Guidelines For Monitoring The Worldwide Average Sulphur Content Of Fuel Oils Supplied For Use On Board Ships (Resolution Mepc.192(61)).

Stationary Source Division. (2007). 2007 Ocean-Going Ship Survey Summary of Results. California Environmental Protection Agency, Air Resources Board.

Patrik, EIF. (2008). Shore-Side Power Supply. Thesis, Masters Program in Electric Power Engineering, Chalmers University of Technology, Goteborg-Sweden.

Samosir, D. H., Markert, M., \& Busse, W. (2017). The Technical and Business Analysis of Using Shore Power Connection in The Port of Hamburg. Jurnal Teknik ITS.

Tarnapowicz, D. (2011). An alternative power supply: the use of ships in port as an environmentally friendly solution. Management Systems in Production Engineering, 304. 